\title{
Perceptions of extended concurrent speech in Mandarin
}

\author{
Weihua Zhu \\ University of Wisconsin, Madison
}

In this paper, we adopt Kádár and Haugh's (2013) discursive-interactional approach to argue that extended concurrent speech for floor taking or topic switching can be perceived as normal and qiàdàng (appropriate). Spontaneous mundane conversations and interviews in Mandarin were collected and transcribed by means of interactional sociolinguistic methods. A close analysis was conducted on participants' responses to the extended concurrent speech for floor taking or topic switching and their retrospective thoughts. Results show that the participants did not view the speech as inappropriate. They produced the speech to achieve relational goals, clarify things, collaborate on a topic, claim participatory rights or display high involvement. They enjoyed conversing around a trivial topic in informal settings. This challenges the argument of long overlapping, floor taking or topic switching as problematic in the literature. The findings indicate the importance of embracing different perspectives from varying sources to understand perceptions of turn-taking mechanisms in Mandarin conversation. This study can contribute to our understanding of interpersonal pragmatics and the conventional views/norms that might cause communication misunderstanding in cross-cultural contact.

Keywords: simultaneous speech, floor, topic, perception, qiàdàng (appropriate), Mandarin

\section{Introduction}

Turn-taking mechanisms have been well discussed from Conversation Analysis (CA) perspectives (e.g. Sacks, Schegloff and Jefferson 1974). This has led to the conclusion that people, at least native English speakers, tend to follow the rule of one party at a time. Brief overlaps might occur but should be resolved fewer than three syllables away from the first speaker's utterance completion place (Schegloff 2000). However, what would happen if the second speaker cuts in to produce 
simultaneous speech that is longer than brief overlaps? How would the first speaker assess and respond to that? Little research has addressed these questions.

In this paper, we make a preliminary attempt to answer the above questions from non-CA perspectives, based on spontaneous conversations among relatively equal-status, non-familial Mandarin speakers and follow-up interviews with some of the participants. We explore the participants' perceptions of extended concurrent speech that emerged for floor taking or topic switching. The concept 'extended concurrent speech' captures the feature of long simultaneous speech initiated by the second speaker more than three words away from the first speaker's utterance completion point. Word here means cí instead of $z i$ (character) in Chinese. This definition highlights the meaning of the extendedness of the concurrent speech under study. Extended concurrent speech differs from overlap discussed in the CA literature in that overlap is brief (e.g. Levinson 1983; Schegloff 2000). Overlap is often resolved to one single speaker when all other interactants stop talking before the third syllable of simultaneous speech (Schegloff 2001). To our best knowledge, extended concurrent speech has rarely been discussed previously.

We focus on extended concurrent speech that allows the second speaker to take the floor or change the current topic in ongoing conversation because unexpected floor taking or topic switching has been implicitly associated with inappropriateness (e.g. Coon and Schwanenflugel 1996; Covelli and Murray 1980; Goldberg 1990; Murata 1994). The floor is "the cognitive entity which develops between/among the interactants...in a conversational activity" (Hayashi 1988:272), or the coherent content of a conversation. Floor taking means that the second speaker develops the first speaker's topic-in-progress but gains control of the content. Topic switching refers to the second speaker bringing up a new topic to replace the current topic. These definitions help us categorize tokens into extended concurrent speech for floor taking and extended concurrent speech for topic switching respectively.

It is important to uncover Chinese speakers' pragmatic perceptions of extended concurrent speech for floor taking or topic switching. This effort could help prevent miscommunication in the cross-cultural interaction that involves China. Since there is a paucity of research on this issue, we intend to contribute to extant knowledge on it. A close analysis of the data collected shows that the participants perceived extended concurrent speech for floor taking or topic switching as appropriate, or qiàdàng in Mandarin. In what follows, Section 2 discusses Kádár and Haugh's (2013) discursive-interactional approach and relevant research on Chinese pragmatics. Section 3 introduces data and analytical methods employed in this study. Section 4 analyzes and discusses the participants' responses to extended concurrent speech for floor taking or topic switching in ongoing conversations and their retrospective thoughts on the speech revealed in follow-up interviews. Section 5 is a conclusion. 


\section{Understanding extended concurrent speech from different perspectives}

We attempt to demonstrate whether extended concurrent speech for floor taking or topic switching is viewed as appropriate or not. Understanding politeness issues like this should rely on varying perspectives, as proposed by Kádár and Haugh (2013). Comprehensive perspectives about politeness cannot be derived from an ideal native speaker's single utterances, as a traditional school of thought suggested (e.g. Lakoff 1973; Leech 1983; Brown and Levinson 1987). Participants' evaluative perspectives can be disclosed by a postmodern discursive approach to politeness that emphasizes the fluidity and relativity of politeness (e.g. Eelen 2001; Mills 2003, 2011; Watts 2003, 2005; Locher 2004, 2006; Locher and Watts 2005). This approach discourages generalizations beyond small-scale communities of practice. But it might not meet the needs of the studies that require attention to relational history and culture in addition to local specificities.

To gain diverse insights, Kádár and Haugh (2013) advanced a holistic discursive-interactional approach to politeness analysis that welcomes a broad range of methods and data types, such as historical texts, spontaneous conversations, discussion boards, interviews and diaries. Politeness would be better comprehended with "(i) participant/metaparticipant understandings (first-order), (ii) emic/etic conceptualisations (first-order), (iii) analyst/lay-observer understandings (second-order), and (iv) theoretical/folk-theoretic conceptualisations (second-order)" (Kádár and Haugh 2013:6). Politeness needs to be understood with reference to the time and space concerning the language used or the actions involved. This indicates the necessity to investigate both historically and locally situated contexts of language or social actions. Also, understanding politeness requires a look at the relationships among participants and the cultural environment where they live. Humans are autonomous social beings who develop cultural expectations of how to speak and act appropriately; meanwhile, their perceptions, speech and behavior are shaped by their social surroundings. Politeness engages a set of expectancies of social actions and meanings that are open to evaluations.

Understanding politeness from varying perspectives is vital because the same utterance may assume "different readings and interpretations based on interpersonal context" (Nodoushan 2012: 134). We should consider the "unfolding of understandings and interpretations" regarding the goals, emotions and relationships of interactants (Bennett 1981: 184), and include both analysts' and participants' perspectives. Analysts' perspectives alone might not accurately reflect interactants' insights concerning how linguistic forms are expected and interactional norms are shaped within communities of practice (see Mills 2009; Garcés-Conejos Blitvich 2013). Similarly, participants' perspectives alone may not be conclusive, systematic and comprehensive (Haugh 2007). Therefore, in this paper, we look into the 
perceptions of extended concurrent speech for floor taking or topic switching through both analysts' and participants' lenses. Along with the participants' viewpoints, we, the viewers, provide metaparticipants' insights. We also discuss theoretical conceptualizations in the literature and folk-theoretic conceptualizations derived from follow-up interviews. We present etic perspectives as outsiders of the participants' community, and emic perspectives of the community members revealed in the interviews.

Whether extended concurrent speech for floor taking or topic switching is appropriate or inappropriate has not attracted attention in Chinese politeness research. Studying it has to be situated in the theoretical conceptualizations of Chinese sociopragmatics. The word 'appropriate' may be equivalent to qiàdàng in Mandarin. According to Xiàndài Hànyŭ Cídiăn (Modern Chinese Dictionary), qiàdàng is an adjective describing the properness of speech and behavior. In hierarchically structured historical China, it was expected for people to comply with lǐyí 'rituals' (Gou 2002; Kádár 2013). On any occasion, it was qiàdàng for low-ranking people to show reverence for high-ranking people. Those with lower status should employ other-elevating forms of address and expressions, such as dàrén 'your honor', zūnfūrén 'your respectable wife' or guifü 'your precious home', towards those with higher status. Conversely, they used self-denigrating terms, such as xiăorén 'this humble person', yúqī 'my humble wife' or bishè 'my shabby place', to depict themselves or their families (Kádár and Pan 2011). Along with honorifics, people emphasized others' long-term interest when delivering refusals in words that have other-elevating and self-denigrating meanings (Kádár 2012). They recognized rank differences and followed the rule of zūnbēi yŏuxù 'pecking order'. Young or lower-ranking people yielded to old or higher-ranking people in turn taking (Gao 1998; Lin 1939). All those helped the elite to keep social order (jüngrán yŏuxù or zhixù jĭngrán). Violating the expected rules of lü 'social hierarchy or politeness' in historical China would not be considered qiàdàng. A serious violation would result in severe punishment $(\mathrm{Gu} 1990)$ such as bōluàn fănzhi 'to suppress the rebellion and restore normal order'.

Nevertheless, what is deemed qiàdàng in Chinese has changed in some way since China went through drastic sociocultural evolution. After the Communist takeover in 1949, anti-traditionalism prevailed. During the Cultural Revolution (1966-1976), jiùsīxiăng 'old thinking', jiùxíguàn 'old customs', jiùwénhuà 'old culture' and jiùchuántŏng 'old tradition' were eradicated, with which conventional politeness expressions were removed. Interestingly, a call for restoring NeoConfucian ideologies (Chan 1963) and traditional practices emerged, after the initiation of the Open Door Policy in 1978 allowed the influx of Western ideologies in China. In 1981, a campaign called wŭjiăng-simĕi 'five stresses and four beautifications' was proposed. Six of them were relevant to politeness, encompassing 
jiăngwénming 'be civilized', jiănglǐmào 'be polite', jiăngzhìù 'be orderly', jiăngdàodé 'be ethical', yŭyánměi 'beautify your language', xīnlíngmĕi 'beautify your heart' and xíngwéiměi 'beautify your behavior'. Later, the Smile Campaign prior to the Beijing Olympics was launched to improve civilians' etiquettes (Chong 2011). All those efforts might have helped maintain the tradition of observing the order of speaking among people of status difference in academic, business, official or family settings. In these situations, higher-status Chinese speakers take more speaking turns and speaking time. Speaking out of turn in the hierarchy would transgress tacit politeness rules and be judged as not qiàdàng (Pan 2000a). However, previous research has not disclosed whether relatively equal-status, non-familial Mandarin speakers would consider extended concurrent speech for floor taking or topic switching in informal conversations a breach of politeness rules or not.

Despite the wŭjiăng-simĕi campaign, conventionally mandatory politeness expressions such as honorifics have declined and been substituted by new ways of thinking and social practice that embrace the ideal of equality. Pan and Kádár (2011:90) posited that subtle discursive strategies, including "the use of tone words, topic introduction, order of speaking, question-answer pattern, turn-taking, small talk, code-switching, joking tone, bantering, irony, teasing or mocking", seem to be used systematically in contemporary Chinese politeness practice. Unfortunately, they did not describe how relatively equal-status, non-familial Chinese speakers take turns. Other researchers (Zhu and Boxer 2013; Zhu 2014a, 2014b) have found flat tone, low pitch and soft volume useful to make strong disagreement sound qiàdàng in everyday life. What would not be considered qiàdàng in historical China is that Chinese people in Beijing employed direct requests more frequently than indirect ones (Lee-Wong 1994, 2000). Those living in Xi'an, China, overwhelmingly accepted compliments (Chen and Yang 2010), instead of rejecting compliments. Cantonese perceived compliment acceptance as appropriate or preferred (Rose and Ng 2001). Native Chinese speakers praised themselves or their families (Wu 2011, 2012). Chinese businessmen ignored facework with new customers (Pan 2000b) or exploited strategic embarrassment to regular customers (Chang and Haugh 2011). All these findings mean that politeness expressions have changed in China to some extent, which may affect the perceptions of extended concurrent speech for floor taking or topic switching in everyday conversation. ${ }^{1}$

As a part of turn-taking mechanisms, extended concurrent speech in Mandarin has not been well studied despite the research already conducted on

1. It is important to note that recent campaigns for the study of Chinese classics, i.e. guóxué cháo, have led to the restoration of some traditional rituals and formal ceremonies such as weddings and funerals (Jin 2007, 2008; Jiang 2008; Kádár 2013). No similar claim has been made about informal face-to-face conversations in Mandarin, though. 
turn taking. For instance, Liu $(1992,2004)$ and Ma (2014) defined the construct of turn in Mandarin. Wu $(1997,2014)$ examined Chinese speakers' turn-entry devices. Yang (2011) and $\mathrm{Li}$ (2014) portrayed the nonverbal aspects of turn taking. $\mathrm{Gu}$ (1999) pointed out the functions of the current turn in relation to the previous turn and the following turn. Liu (2007) summarized how to grab a turn or keep the floor. Gao (2012) described varying signals of yielding the floor. Ulijn and Li (1995), Li $(1999,2001)$ and Liao (2009) presented interruptions in different discourses. Liu (2004) and Kuang (2005) teased out the varieties of interruptions in Chinese. Kuang (2006) discussed different types of overlapping, causes of overlapping and solutions to overlapping, assuming that long overlapping is problematic. Nevertheless, few researchers have investigated whether extended concurrent speech for floor taking or topic switching in mundane conversation in Mandarin is qiàdàng or not. Therefore, we attempt to uncover the participants' perceptions by analyzing their responses to this type of simultaneous speech in ongoing conversational interactions. The perceptions are corroborated by the participants' insights disclosed in follow-up interviews.

\section{Method}

We adopt interactional sociolinguistics (Gumperz 1982, 2005, 2006) to analyze and interpret participants' perceptions of extended concurrent speech for floor taking or topic switching. This approach, sometimes "known as a microethnography, is a methodological approach to interactional analysis using video-taped data and taking into account non-verbal behavior such as facial gestures, postural shifts, and proxemics" in addition to verbal behavior (Boxer 2002:13). It strives to achieve accurate inferences and illustrate why a particular utterance is used in a particular way and how that affects interaction. Watts (2003:217-218) also contended that contextual cues such as "consultative devices", "play-downs", "politeness markers", "hedges", "understaters", "downtoners", "committers" and "forewarnings" are crucial for the interpretation of whether certain behavior is appropriate or not.

The first part of the data was drawn from approximately 97 hours of recorded spontaneous conversations in Mandarin in a southeastern city of mainland China. ${ }^{2}$ These mundane conversations occurred in various places such as a restaurant, a condo or a community center where relatively equal-status, non-familial

2. Although recording spontaneous conversations might have caused an observer's paradox (Labov 1972), the participants seemed to forget the existence of a recorder as they became more and more engaged in their conversation. The data were transcribed following Schiffrin's (1987) conventions (see Appendix A) and glossed according to Li and Thompson (1981) (see Appendix B). 
interactants chatted about trivialities. Participants were approached through friends and acquaintances. They were told that this project aimed to investigate native Chinese speakers' communication style in everyday life and that they should speak the way they normally do. Before data collection, we had no idea what would appear as salient interactional features that would be worth researching. When examining the data, we found extended concurrent speech for floor taking or topic switching salient and made it the unit of analysis. Simultaneous speech beyond the third syllable, floor taking or topic switching has been implicitly associated with impoliteness in the literature (e.g. Schegloff 2000; Goldberg 1990), although the interactants in the conversations collected seemed to deem it normal. Due to space limit, only six instances of extended concurrent speech were selected for detailed analysis in this paper. ${ }^{3}$

Interactants often make assessments about each other in ongoing conversations and respond accordingly (Mori 1999). If they assess the previous speaker's words as appropriate and inviting, they may well enjoy the conversation and actively contribute to it; otherwise, they are likely to show signs of unhappiness or respond negatively (Culpeper 1996, 2005; Culpeper, Bousfield and Wichmann 2003; Culpeper et al. 2010; Langlotz and Locher 2012). Therefore, we identified and analyzed participants' perceptions through their interaction before, when and after extended concurrent speech for floor taking or topic switching was delivered. We compensate analysis of our conversational data with follow-up interviews because metapragmatic data could be valuable tools for achieving knowledge about extended concurrent speech for floor taking or topic switching. They give us access into first-order understandings of politeness (Jaworski et al. 2004; Schneider 2012; García and Terkourafi 2014).

The second dataset came from recorded semi-structured interviews with ten of the participants conducted in the week after their conversations were collected. The interviewees might be the first speaker whose speech was overlapped by the second speaker, the second speaker who initiated extended concurrent speech, or "side participants" who were not directly addressed (Kádár and Haugh 2013: 88). They were invited to watch three clips of conversations involving extended concurrent speech for floor taking (Excerpts 1, 2 and 3) and another three clips involving extended concurrent speech for topic switching (Excerpts 4, 5 and 6). Right after watching each clip, they were asked whether they had noticed anything abnormal in the conversations. Then, they evaluated the instances of extended concurrent speech for floor taking or topic switching that emerged in the clips, and justified their evaluations. They also explained why they thought the instances

3. Token selection was discussed with a Chinese-speaking college teacher in the city of data collection. 
appeared that way. The interviewees provided us with retrospective perceptions of the speech and enlightening insights. Each of them was interviewed alone in Mandarin for about thirty minutes and promised anonymity.

\section{Results and discussion}

In this section, we present understandings of extended concurrent speech for floor taking or topic switching from various perspectives. The analyst's understanding is displayed in the analysis of the speech in prior, current or subsequent talk. The participants' reactions can demonstrate their momentary assessments and perceptions of previous utterances. Their understandings are also reflected in their judgements of the six instances of the speech in the follow-up interviews. Three examples from each category are presented for close analysis. It is important to note that a few participants deployed extended concurrent speech to switch the topic and take the floor at the same time in some situations. Detailed analysis showed that the participants assessed the six instances in ongoing conversations as normal. They responded to the occurrence of the speech without any negative evaluations, emotionally loaded words or nonverbal signs of unhappiness. The ten interviewees stated that they were unaware of extended concurrent speech for floor taking or topic switching until it was pointed out. They overtly commented on the six instances as qiàdàng in everyday conversations in their community. Examples and comments follow.

\subsection{Extended concurrent speech for floor taking}

Since the participants' assessments in ongoing conversations can be reflected by how they responded to extended concurrent speech, six instances are analyzed in detail to display the participants' assessments in ongoing conversations in Mandarin. Excerpts (1)-(3) exemplify the participants' reactions to extended concurrent speech for floor taking. In the first excerpt, Wáng, a female college English teacher, and Xióng, a male state employee, were in their forties. Jiàn was a female Ph.D. student in her thirties. Wáng and Xióng were friends who met regularly. Wáng and Jiàn were also friends for many years. On the day of data collection, Wáng arranged a dinner at a restaurant for Jiàn to meet Xióng for the first time, hoping that they could become acquainted. This is typical for social network expansion in China (Yang 1994). Since Xióng often served as a correspondent of his workplace, Jiàn asked him what he would do if he and his co-worker disagreed on a news article. He tried to avoid answering this question by claiming that this never happened in his real life. But Jiàn was persistent in seeking an answer from him. 
(1) (Xiong)

1 Jiàn:(looks at Wáng and then Xióng)

Dui ya. Xiànzài wŏmen jiùshi

right $\mathrm{RF}$ now 1PL just

2 láiyuán-yú shēnghuó ér gāo-yú shēnghuó. Láiyuán-yú come:from life but high:than life come:from

3 [wŏ de jiào-xué jīngyàn, gāo-yú]

1SG GEN teach:learn experience high:than

'Jiàn: (looks at Wáng and then Xióng) Right. Now it does come from life and larger than life. It comes from my teaching experiences but larger than'

4 Xióng: (looks at Jiàn)

[Dànshì dànshì dànshì qümă nī] nàge

but but but at:least 2SG that:CL

5 jiăshè yào yŏu shēnghuó jīchŭ $a$, duì ba?

hypothesis must have life basis RF right $\mathrm{SA}$

'Xióng: (looks at Jiàn) But at least your hypothesis needs a basis from life, right?'

$6 \rightarrow$ Jiàn: (looks at Xióng)

Ài, wŏ de shēnghuó jīchŭ $a$. Wŏ

INT 1 SG GEN life basis RF $1 \mathrm{SG}$

7 [jiāo xuéshēng. Wŏ gēn nŭ shuō le.

teach student $1 \mathrm{SG}$ with $2 \mathrm{SG}$ talk PFV

8 Wŏ jiāo wŏ de xuéshēng jiù]

1SG teach 1SG GEN student just

'Jiàn: (looks at Xióng) Ài, it's based on my life experience. I teach students, as I told you. I teach my students just'

9 Xióng: (looks at Jiàn)

[Méi-yŏu shēnghuó jīchŭ. Nĩ zěnme jiù

not:have life basis 2sG how just

10 hăoxiàng kōngzhōnglóngé yíyàng. Wŏ cónglái] méi-yŏu, wŏ like castle:in:the:air same 1sG ever not:have 1sG

11 méi-yŏu méi-yŏu zài nà lóngé zhù guo, nà wŏ not:have not:have in that castle live PFV then 1SG

12 [jiù méi zhège tĭhuì ma.]

just not this:CL experience RF

'Xióng: (looks at Jiàn) I don't have that life experience. You were just like living in a castle in the air. I've never lived there, so I don't have that experience.' 
13 $\rightarrow$ Jiàn: (looks at Xióng)

[Méi-yŏu, méi-yŏu, yŏu jīchŭ,] wŏ yŏu

not:have not:have have basis 1sG have

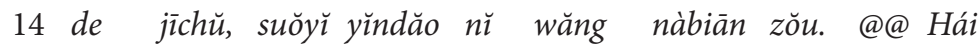
NOM basis so lead 2sG toward there walk still

15 méi-yŏu huídá wŏ de wèntí. @@ not:have answer 1SG GEN question

'Jiàn: (looks at Xióng) No, no, I have basis. I have basis. So I'm trying to lead you that way. (laughs) But you haven't answered my question. (laughs)'

16 Wáng: (looks at Jiàn)

Éi, suŏy̆ [zhè shì]

INT so this be

'Wáng: (looks at Jiàn) Éi, so this is'

17 Jiàn: (looks at Wáng)

[Tā zhè] háishì shŭyú büjiào

3SG this still belong:to relatively

18 jiànjiē de. (turns to Xióng) Shì-bú-shi?

indirect NOM be:not:be

'Jiàn: (looks at Wáng) He is relatively indirect. (turns to Xióng) Isn't it?'

19 $\rightarrow$ Xióng: (looks at Jiàn)

Shi, shi, shì. (smiles)

be be be

'Xióng: (looks at Jiàn) Yeah, yeah, yeah. (smiles)'

In Excerpt (1), Jiàn and Xióng do not seem to share the understanding that Jiàn's hypothetical question was based on life experience. In lines 4 and 9-10, Xióng produces extended concurrent speech to express strong disagreement with Jiàn's understanding of the question. He does not appear to act like a supportive secondary speaker who only provides brief comments or asks clarification questions (Hayashi 1990, 1991). Instead, he takes over the floor to make the point that he does not have real-life experiences to answer Jiàn's hypothetical question (lines 4-5 and 9-12). It is more interesting to see that Jiàn responds to the first extended concurrent speech for floor taking with a patient explanation (lines 6-8) but the second one with another extended concurrent speech (lines 13-15). Xióng reacts to Jiàn's speech that takes away his floor by answering her question lightheartedly (line 19). Jiàn's and Xióng's con-constitution of and reactions to extended concurrent speech for floor taking suggest that they assess the speech as qiàdàng. This might result from their 
relational goal of rapport establishment and enhancement (Spencer-Oatey 2008). In the follow-up interview, Xióng explained that they could not avoid long simultaneous speech when actively engaged in showing their disparate understandings. This indicates their excitement in both chatting and making new friends.

I work at the Tax Department of the province, which requires me to meet with all kinds of people. I like to make new friends and expand my social network that I might be able to use to my advantage in the future. Talking with Jiàn was fun and helped me understand her field of study. When I got excited, I intervened to express my opinion because it was relevant to what had just been said. Jiàn also did that because she was very engaged too. Although we disagreed sometimes, it didn't hurt our face at all. We supported each other in making our points clear. We talked, interacted and built our relationship. I don't think that was not qiàdàng. If you didn't point out the simultaneous speech to me, I wouldn't have noticed that.

(Xióng's explanation in an interview)

The following conversation occurred outside of a condo where Juàn and Hŭ were waiting for their elementary school boys to finish spoken English practice. Juàn was a Ph.D. student in her early thirties, and Hŭ was a sales representative in his late thirties. They lived in different school districts but became acquainted when their sons joined the same learning center a couple of months ago. They had met twice before they took their sons to the center to practice speaking English again that day. Since Hŭ mentioned earlier that he spent much time teaching his son extracurricular English materials above grade level, Juàn was curious about how he did it in addition to having a full-time job.

(2) (Xiaohu)

1 Juàn:

Duì. Nĭ jiāo nù érzi, nă yŏu nàme duō shijiān ne? right 2sG teach 2 sG son where have so much time Qne

2 Wŏ juéde wŏmen liăngge rén zài nàbiān tèbié 1sG think 1PL two:CL person at there very

3 máng a, yālì tèbié dà, busy RF pressure very big

4 [wŏ juéde méi-yŏu shíjiān] 1sG think not:have time

'Juàn: Right. How do you find so much time to teach your son? I think we're so busy there and our pressure is so big that I don't think we have time' 
$5 H \check{u}:$

[Wŏ găo xiāoshòu de, wŏ] găo xiāoshòu de

$1 \mathrm{SG}$ do sales NOM $1 \mathrm{Sg}$ do sales NOM

6 gōngzuò, wănshàng kěy̆ jīběnshàng bú-yào shàngbān ma. job at:night can basically not:need work RF

7 Dào wănshàng gàn má ne? Wănshàng hèn qīngxián, arrive night do what Qne at:night very leisurely

8 méi-yŏu nĭmen nàme_jiézòu nàme kuài, zhìdào ba? Wŏmen zhè not:have 2PL so pace so fast know SA 1PL here

9 wănshàng shijiān yibān dă-xià-pái.

night time generally play:cards

'Hŭ: I'm a salesman. Basically, I don't need to work at night. So what do I do in my free time? My life pace is not as fast as yours, you know. Generally, we play cards at night.'

$10 \rightarrow$ Juàn:

O, dă-pái jiù bùrú jiāo háizi le.

Oh play:cards just worse:than teach kids CRS

'Juàn: Oh, playing cards is not as good as teaching kids.'

Upon hearing about how busy Juàn and her husband are (lines 1-4), Hŭ is eager to show his sympathy by pointing out that he has free time at night (lines 5-9). He acknowledges Juàn's fast-paced lifestyle. He explains his preference of teaching his son over playing cards, although his colleagues prefer the latter in their leisure time. To do all these things, Hŭ produces extended concurrent speech in line 5 and grabs the floor from Juàn. Although this would be deemed problematic (e.g. Schegloff 2000), it confirms the previous finding that interruption can function to clarify things (Kuang 2005). Moreover, Hŭ's expression of understanding Juàn's situation is comforting. His sacrificing entertainment for his son's education seems to resonate with Juàn. As a response to the extended concurrent speech that takes away her floor, Juàn agrees with $\mathrm{Hu}$ for his choice. This alignment indicates that they have reached the same understanding and that Juàn does not consider extended concurrent speech for floor taking not qiàdàng. Interactants can "interrupt and compete for the floor without intending to cause offence" (Holmes 1995: 66).

I don't know Juàn very well, but I do know that it isn't easy to work on a Ph.D. degree and a job while taking care of a kid. When I sensed that she felt guilty about not having time to teach her son extra stuff, I jumped in to clarify that my job is different from hers. I don't need to study for exams or sell things at night. I have nothing else to do when I don't want to play cards with my colleagues. So it's 
very fulfilling for me to help my son study additional English books and get ahead of the game. I don't think Juàn was upset about me starting to talk while she was talking. Cutting in for clarification is normal and typical in Chinese. I couldn't have waited till later because I would have forgotten what I was going to say.

(Hü’s remark during the playback)

Now consider another example. Péng was a senior researcher in his late forties working at a local education bureau, after he had taught English in a college for many years. Huáng was a math teacher of a middle school in his late thirties. Wèiqí was a natural science teacher of an elementary school in her early forties. Péng and Wèiqi were friends whose families regularly dined out together for over ten years. Wèiqí and Huáng were acquaintances for about four years. Since Huáng had the skills of fixing computers and Péng's computer often broke down due to malicious software, Wèiqi introduced Huáng to Péng two years ago. On the day of data collection, Huáng went with Wèiqí to Péng's condo to solve a computer problem. They began to talk about web space that some universities gave to students free of charge.

(3) (Weiqi)

1 Péng: (looks at Huáng)

Zhè shì zhèngcháng de. Wömen yŭqián

this be normal NOM 1PL former

2 xuéxiào [dōu gěi de, suŏyŏude xuéshēng.]

school all give NOM all student

'Péng: (looks at Huáng) This is normal. Our former school gave it to all the students.'

3 Huáng: (looks at Péng)

[Nĩmen méiyŏu méiyŏu yòng.]

2PL not:have not:have use

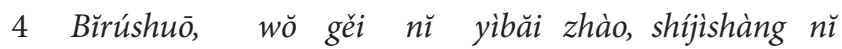
for:instance 1SG give 2SG 100 MB actually 2sG

5 zhŭ yòng le shí zhào.

only use PFV $10 \mathrm{MB}$

'Huáng: (looks at Péng) You wouldn’t need it. For instance, I gave you $100 \mathrm{MB}$, but actually you only used 10MB.'

6 Wèiqí: (looks at Huáng)

Dui. Tā yòngbuliăo zhème duō.

right 3sg cannot:use so much

'Wèiqí: (looks at Huáng) Right. He cannot use that much.' 


\section{$7 \rightarrow$ Péng: (looks at Huáng)}

$\mathrm{Nĩ}$ zhège zhège zhè kōngjiàn bù

2SG this:CL this:CL this space not

8 hái zài zhèlŭ, duibuduì? Hái yŏu jiŭshí zhào hái zài nàlĭ. still at here right:not:right still have $90 \mathrm{MB}$ still at there

'Péng: (looks at Huáng) You still have that much space left, right? You still have $90 \mathrm{MB}$ there.'

Before Péng finishes saying that the news about free web space is not news (lines 1-2), Huáng offers his distinctive perspective that people generally do not need big web space (lines 3-5). Although this perspective is presented in the form of extended concurrent speech for floor taking, Péng does not respond with emotional words, negative evaluation or signs of unhappiness in line 7. He follows Huáng's lead and continues to elaborate on Huáng's example. The extended concurrent speech for floor taking in line 3 seems to result from the speakers' collaboration on the development of the current conversation topic. It discloses their successful endeavor to develop coherent content collectively despite the change in floor holders (Ng, Brooke and Dunne 1995). This behavior can accentuate their "shared goals and values" and signal "solidarity" (Holmes 1995: 67). The three interactants seem to be trying to achieve an understanding about the use of web space.

I believed that everyone was entitled to some free web space, whereas Huáng thought it was a waste of resources for ordinary people to own a large amount of web space. He just couldn't wait to give me a specific example and make a point. I didn't mind him talking with me at the same time because his point was valid. I didn't feel bad at all. Instead, he made me reconsider how to make the best use of my personal web space. We worked together on the topic and heard different viewpoints, although we talked over each other sometimes. That happens very often to us Chinese people. I wasn't aware of the overlapping thing, but I paid attention to the content. The conversation sounds qiàdàng to me.

(stated by Péng in the interview)

\subsection{Extended concurrent speech for topic switching}

Likewise, extended concurrent speech for topic switching can be viewed as qiàdàng, although unexpected topic switching has been found impolite (e.g. Covelli and Murray 1980). Take Excerpt (4) as an example. Jiàn was a Ph.D. student in her thirties. Wáng was a college English teacher in her forties from a different university. They were friends for about fifteen years. Hèpí was a businessman in his thirties who became acquainted with Jiàn at a social event one month ago. On the 
day of data collection, Hèpí invited Jiàn to have some ice cream at a shop because he needed some information about her university. Jiàn took Wáng with her and introduced Wáng to Hèpí. They began to talk about their different career paths after they sat down.

(4) (ChinCorn08-5)

1 Jiàn: (looks at Hèpí and Wáng)

...Wŏ zhìdào wŏ xiăng-yào shénme.

1SG know 1SG want what

2 Tāmen younderén jiù bù zhìdào tā xiăng-yào gàn shénme.

3PL some:people just not know 3sG want do what

3 Tā zhĭshì yizhí zài zhège fängxiàng, zài zhège 3sG only always at this:CL direction at this:CL

4 [xuéxiào guò de, tā jiù méi-yŏu guò] school experience NOM 3sg just not:have PFV

'Jiàn: (looks at Hèpí and Wáng) ...I know what I want. Some of them don't know what to do. They only know this direction. They have stayed only at school. They haven't'

5 Hèpí: (looks at Wáng)

[Xiànzài xiànzài nĭmen zuò dàxué] lăoshī yě

now now 2PL do college teacher also

6 búcuò a. Xiànzài dàxué lăoshī gōngzī mán gāo de good RF now college teacher salary fairly high Nom

7 Yŏu sān sì qiān kuài qián yíge yuè ma? have three four thousand CL money one:CL month Qma

'Hèpí: (looks at Wáng) It's also good to be a college teacher these days. Their salary is fairly high. Do you have three or four thousand RMB each month?'

8 Wáng: (smiles at Hèpí)

Wŏ hèn xiăng gěi nŭ dăgōng.

1SG very want for 2 sG work

'Wáng: (smiles at Hèpí) I'd like to work for you.'

9 Hèpí: (looks surprised)

Nábúdào ma? Bù kènéng ba?

get:not Qma not possible sA

'Hèpí: (looks surprised) You don't get that much? How is that possible?' 


\section{$10 \rightarrow$ Jiàn: (smiles at Hèpí)}

Hăo căn de, suŏyı̆ rénjiā yào gěi nŭ dăgōng. very tragic NOM so other want for $2 \mathrm{sg}$ work 'Jiàn: (smiles at Hèpí) That's very sad. So she wants to work for you.'

In the middle of Jiàn's utterances (lines 1-4), Hèpí seizes the floor by making a comment that is irrelevant to Jiàn's words, and switches the topic to college teachers' salary (lines 5-7). Some of his words appear in the form of extended concurrent speech. Also, the unexpected question is incoherent with the previous content. All these would be deemed inappropriate (e.g. Goldberg 1990). But the interactants apparently accept the change. Wáng jokes about the possibility of working for Hèpí to earn the amount of the money Hèpí suggested (line 8), and Jiàn aligns with her (line 10). Jiàn's response is presented in a joking tone along with a smile on her face. None of these indicates any negative impact caused by Hèpí's production of extended concurrent speech for topic switching (and floor taking at the same time in this case). Hèpís speech seems qiàdàng to Jiàn. This might be due to the fact that Jiàn has finished talking about her own career choice and begun to compare herself with others that Hèpí has no interest in (lines 2-4). She respects Hèpí's participatory rights (Bennett 1981; Edelsky 1981; Murray 1985) to start a new topic that involves Wáng who has been quiet.

I was very happy to get to know Jiàn and Wáng who are successful academically. I wanted to know how they started their careers and hoped to learn something from them. When Jiàn talked about her experiences in her field, Wáng didn't say anything. Later, Jiàn digressed into other people's choices that I wasn't interested in. So I rushed to comment on Wáng's career and direct my question to her. Then she was engaged. I know I talked at the same time with Jiàn, but that was qiàdàng. Both she and Wáng did that in our conversations too. We were just chitchatting. We jumped from one topic to another, following our random thoughts. The good thing is that you don't have to face consequences in everyday talk like this.

(Hèpí during the playback)

Likewise, in Excerpt (5), Xin also switched the current topic and took over the floor when she started to talk simulatenously with Jiàn. This did not seem to be assessed as impolite either. Xīn, Yí and Jiàn were three female acquaintances from different universities in their thirties. Xīn was an associate professor, Yí was a lecturer, and Jiàn was a Ph.D. student. Xīn and Yí shared the experience of working as visiting scholars at an American university for half a year. The three of them became acquainted through a professor they knew a couple of months before the day of data collection. Prior to this part of the conversation, they talked about their surprising discovery that Americans do not heat drinking water in winter, whereas most Chinese people would. 
(5) (ChiScho2)

1 Jiàn:

Duì ya. Bú-cuò bú-cuò, lái le cái

right RF not:bad not:bad come PFV only

2 [yíge duō yuè jiù yìjing shìying le.] one:CL more month then already accustomed CRS

'Jiàn: Right. It's good that you've gotten used to it although you've been here only a little over one month.'

3 Xìn:

[Jiù juéde qishí tĭng hăowán de,] jiù juéde just think actually very fun NOM just think

4 měicì dōu jingcháng huì pèngdào yíge wèntí. every:time all often will run:into one:CL problem

'Xīn: I just thought it actually fun. I often run into a problem (like this).'

$5 \rightarrow$ Jiàn:

Xìnxiān de dōngxī ha, hăo xīnxiān de dōngxī, fresh Assoc stuff RF very fresh Assoc stuff

6 ň̀ kènéng yào pèng hăojiŭ nŭ cái néng 2sG maybe need run:into very:long 2sG then can

7 pèng-wán. Wŏ hái bù-yìding pèngdewán. run:out 1SG still not:necessary run:out

'Jiàn: It might take you a very long time to stop running into those problems. I might not even be done with that.'

8 Yí:

Dui.

right

'Yí: Right.'

9 Jiàn:

Píngcháng chūqù zhuànyōu

on:week:days go:out stroll

10 [zhuànyōu, kànkàn biérén zĕnme zuò.]

stroll look others how do

'Jiàn: You should get out and walk around on weekdays. Take a look at how others do things.'

11 Xìn:

[Ránhòu wŏ nàtiān nàtiān pèngdào] yíge

then 1SG that:day that:day run:into one:CL 
12 făngwèn xuézhĕ, ránhòu zhènghăo zài chē visiting scholar then coincidentally on bus

13 shàng pèngjiàn tā, wèn tā gàn má. above run:into $3 \mathrm{sg}$ ask $3 \mathrm{Sg}$ do what

14 [yíge făngwèn xuézhĕ] one:CL visiting scholar

'Xin: Then, that day, I ran into a visiting scholar on the bus coincidentally. I asked him what he was up to, a visiting scholar'

$15 \rightarrow$ Jiàn:

[Nă gè xì de?]

which CL department NOM

'Jiàn: Which department?'

16 Xìn:

Hăoxiàng shì gè, shi lïkē de nàzhŏng

seem be CL be science ASSOC that:CL

17 shénme shénme dōngxī...

what what stuff

'Xīn: He seems to be in a science department or one like that...'

Xīn's comment in line 3 overlaps with Jiàn's words in line 2. This extended concurrent speech results in a change in the floor holder but does not seem to annoy Jiàn because she sympathizes with Xīn (lines 5-7). When she makes a suggestion in lines 9-10, Xīn produces another extended concurrent speech to take over the floor and also switch to a new topic about a visiting scholar (lines 11-14). As a response, Jiàn embraces the abruptly changed topic and asks a question about the scholar (line 15). She appears to perceive Xīn's behavior as qiàdàng. Jiàn's question overlaps with Xīn's words in line 14. But Xīn does not seem to view it as not qiàdàng either. She simply answers the question. All these might result from their “joint enthusiasm” (Natale, Entin and Jaffe 1979: 875), high involvement (Tannen 1984), and shared understanding of how to interact. It could also be related to the fact that the conversation revolves around trivialities that do not involve conflicts of interest. The choice of topic affects people's informal reasoning (Kuhn 1991) and can also influence people's perceptions of interrupters (Chambliss and Feeny 1992).

We had very interesting experiences in the U.S. We just had to share the fun trivia and our feelings. The topics weren't confrontational and didn't cause any face loss. We laughed about the eye-opening incidents resulting from cultural differences. We all wanted to tell what happened to us unexpectedly. It was natural for us to intervene in each other's story telling because we were eager to share or were curious with questions. Wasn't it a good thing for us to get engaged despite the 
resulting overlapping talk? I was so interested in the content that I didn't notice overlapping. We should get together more often because topics like this are educational as well. We can learn about everyday life in foreign countries from those incidents.

(uttered by Xīn during the interview)

In addition to interesting topics, informal setttings could eliminate the negative effect of extended concurrent speech for topic switching. In Excerpt (6), Zhì and Qiàn were acquaintances in their thirties who met at their high school reunion in the city of data collection. They had participated in class reunions a few times over the years before. Although they had gone to the same middle school and high school, they had communicated very little until they had stable jobs in different cities many years later. Zhì was a male secretary of a Youth League Committee and Qiàn was a female college teacher. Prior to this part of the conversation, Qiàn talked about her visit to a cancer patient at a hospital before he died, which made her realize the importance of appreciating things and having peace of mind.

(6) (ZhiQian2)

(1) Qiàn:

...Ránhòu juéde wŏ zìǰ kāixīn jiù hăo, yīnwèi

then think 1SG self happy just fine because

2 nàge tāmen zuì kànzhòng de shì jīngshén shēnghuó that:CL 3PL most value NOM be spirit life

3 ma. Wŏ jiù juéde [tèbié yŏuyìsi yě tèbié hăo.] RF 1sG just think very interesting also very good

'Qiàn: ...Then, they think everything is fine as long as I'm happy, because they value their spiritual life most. I think that's very interesting and very good.'

4 Zhi:

[Ň̌ shi kàn zhŏngliú bingrén]

2sG be see cancer patient

5 dào năge difāng? Shànghăi?

arrive which place Shànghăi

'Zhì: Where did you go to see a cancer patient?'

$6 \rightarrow$ Qiàn:

Wŏ nà cì kàn zhŏngliú bingrén shì zài

1sG that time see cancer patient be at

7 Jiāngxī, Jiāngxī zhŏngliú yīyuàn.

Jiāngxī Jiāngxī cancer hospital

'Qiàn: I went to the Jiāngxī Cancer Hospital to see the patient.' 
Before Qiàn finishes sharing her other friends' values (lines 1-3), Zhì suddently cuts in to ask her where she went to see a cancer patient (line 4). The mention of death might have made Zhì wonder where the tragedy happened. His curiosity results in the construction of extended concurrent speech that switches the current topic about values to the old topic about cancer. However, Qiàn does not seem to evaluate Zhì's behavior as not qiàdàng because she follows the flow to answer his question (lines 6-7). Her response signals that she does not expect Zhì to take turns speaking in such an informal setting. In different contexts, any points on the continuum of orderly turn-taking and extended concurrent speech could be sanctioned. "Which point on the scale is 'optimum' depends partly on pragmatic contextual variables and partly on culturally-based sociopragmatic preferences" (Spencer-Oatey and Jiang 2003: 1635). Qiàn's peaceful reaction also shows that interactants' judgments can occur on the spot. They "draw from certain sets of expectancies in co-constructing interaction in localized, situated contexts" (Kádár and Haugh 2013: 137). Qiàn's and Zhì's relational history as old classmates could help us understand Qiàn's familiarity with Zhì's production of extended concurrent speech for topic switching.

In formal contexts, interrupting and switching topics like that are not qiàdàng. But in informal contexts, we don't usually wait for people to complete their sentences. We often jump in when we want to express our opinions on the issue under discussion, help the speaker clarify the issue, need more explanation on the old topic, among other things. We might not be able to remember our point if we wait until the current speaker finishes. In this case, I didn't mind Zhì's interruption to change the topic because we were just catching up, nothing serious. I know what kind of person he is. I understand that he was eager to ask his question because we would have gone too far from it. (commented by Qiàn during the playback)

\section{Conclusion}

In this paper, we argued that our participants construed extended concurrent speech for floor taking or topic switching as normal and qiàdàng. The argument was based on the participants' reactions to the occurrence of the speech in the ongoing conversations and their retrospective perceptions of the speech revealed in the follow-up interviews. This indicates that extended concurrent speech might be another "type of practice that is open to evaluation as face-threatening, yet appears difficult to characterize as either polite or impolite" (Chang and Haugh, 2011:2961). From the perspectives of Kádár and Haugh's (2013) discursive-interactional approach to politeness analysis, we triangulated conversational data with post-interaction interviews to present empirical evidence. We discussed emic/etic 
and theoretical/folk-theoretic conceptualisations, and provided analyst/lay-observer and participant/metaparticipant understandings. The findings can enhance our understanding of the interactional functions of this type of speech, since it has rarely been explored before, and turn-taking mechanisms in Mandarin conversation. We aimed to contribute to the research on conventional views and norms associated with floor taking or topic switching, actual use of extended concurrent speech in spontaneous conversations, and interactants' assessments and perceptions thereof. However, we acknowledge that the interviewees' comments might be limited by sensitivity to face. Also, in other regions including Taiwan and Hong Kong, people might have different assessments and perceptions of extended concurrent speech for floor taking or topic switching.

\section{Acknowledgements}

This study is part of a larger research project that was partially funded by Language Learning. I am grateful to Prof. Jun Wang who offered help with this project. I also want to thank the editor and the anonymous reviewers for their comments on earlier versions of this paper. Any remaining errors are my own.

\section{References}

Bennett, Adrian. 1981. "Interruption and the Interpretation of Conversation." Discourse Processes 4: $171-188$.

Boxer, Diana. 2002. Applying Sociolinguistics: Domains and Face-to-Face Interaction. Philadelphia, Pennsylvania: John Benjamins.

Brown, Penelope, and Stephen Levinson. 1987 Politeness: Some Universals in Language Usage. Cambridge: Cambridge University Press.

Chambliss, Catherine A., and Norah Feeny. 1992 "Effects of Sex of Subject, Sex of Interrupter, and Topic of Conversation on the Perceptions of Interruptions." Perceptual and Motor Skills 75: 1235-1241.

Chan, Wing-Tsit. 1963. Instructions for Practical Living and Other Neo-Confucian Writings by Wang Yang-ming. New York: Columbia University Press.

Chang, Wei-Lin Melody, and Michael Haugh. 2011. "Strategic Embarrassment and Face Threatening in Business Interactions." Journal of Pragmatics 43: 2948-2963.

Chen, Rong, and Dafu Yang. 2010. "Responding to Compliments in Chinese: Has it Changed?" Journal of Pragmatics 42 (7): 1951-1963.

Chong, Gladys Pak Lei. 2011. "Volunteers as the 'New' Model Vitizens: Governing Citizens through Soft Power." China Information 25 (1): 33-59.

Coon, Christine A., and Paula Schwanenflugel. 1996. "Evaluation of Interruption Behavior by Naïve Encoders." Discourse Processes 22 (1): 1-24. 
Covelli, Lucille H., and Stephen O. Murray. 1980. "Accomplishing Topic Change." Anthropological Linguistics 22 (9): 382-390.

Culpeper, Jonathan. 1996. “Towards an Anatomy of Impoliteness." Journal of Pragmatics 25 (3): 349-367.

Culpeper, Jonathan. 2005. "Impoliteness and Entertainment in the Television Quiz Show: The Weakest Link." Journal of Politeness Research 1 (1): 35-72.

Culpeper, Jonathan, Derek Bousfield, and Anne Wichmann. 2003. "Impoliteness Revisited: With Special Reference to Dynamic and Prosodic Aspects." Journal of Pragmatics. 35 (10-11): 1545-1579.

Culpeper, Jonathan, Leyla Marti, Meilian Mei, Minna Nevala, and Gila Schauer. 2010. "Crosscultural Variation in the Perception of Impoliteness: A Study of Impoliteness Events Reported by Students in England, China, Finland, Germany, and Turkey." Intercultural Pragmatics 7 (4): 597-624.

Edelsky, Carole. 1981. “Who's Got the floor?” Language in Society 10: 383-421.

Eelen, Gino. 2001. A Critique of Politeness Theories. Manchester, UK: St. Jerome Publishing.

Gao, Ge. 1998. “'Don't take my word for it' - Understanding Chinese Speaking Practices." International Journal of Intercultural Relations 22: 163-186.

Gao, Yang. 2012. “对外汉语课堂话轮分析. [Analysis of turn taking in the Chinese as a foreign language classroom]”. Journal of Language and Literature Studies 12: 136-137.

Garcés-Conejos Blitvich, Pilar. 2013. "Introduction: Face, Identity and Im/politeness. Looking Backward, Moving Forward: From Goffman to Practice Theory." Journal of Politeness Research 9 (1): 1-33.

García, María Jesús Barros, and Marina Terkourafi. 2014. “First Order Politeness in Rapprochement and Distancing Cultures: Understandings and Uses of Politeness by Spanish Native Speakers from Spain and Spanish Nonnative Speakers from the U.S." Pragmatics 24 (1): 1-34.

Goldberg, Julia. 1990. "Interrupting the Discourse on Interruptions: An Analysis in Terms of Relationally Neutral, Power- and Rapport-oriented Acts." Journal of Pragmatics 14: 883-903.

Gou, Chengyi. 2002. 先秦礼学 [Li (Rite) Philosophies before the Qin Dynasty]. Chengdu: BaShu shushe.

Gu, Yueguo. 1990. "Politeness Phenomena in Modern Chinese." Journal of Pragmatics 14 (2): 237-257.

Gu, Yueguo. 1999. “Towards a Model of Situated Discourse Analysis.” In The Semantics and Pragmatics Interface from Different Points of View, ed. by Ken Turner, 150-178. Amsterdam: Elsevier Science Publisher.

Gumperz, John. 1982. Discourse Strategies: Studies in Interactional Sociolinguistics. Cambridge: Cambridge University Press.

Gumperz, John. 2005. "Interactional Sociolinguistics: A Personal Perspective." In The Handbook of Discourse Analysis, ed. by Deborah Schiffrin, Deborah Tannen, and Heidi E. Hamilton, 215-228. Malden, MA: Blackwell Publishers Ltd.

Gumperz, John. 2006. "Interactional Sociolinguistics." In Encyclopedia of Language and Linguistics, ed. by Keith Brown, 724-729. Kidlington, UK: Elsevier Ltd.

Haugh, Michael. 2007. “The Discursive Challenge to Politeness Research: An Interactional Alternative." Journal of Politeness Research 3 (2): 295-317.

Hayashi, Reiko. 1988. "Simultaneous Talk - From the Perspective of Floor Management of English and Japanese Speakers.” World Englishes 7: 269-288.

Hayashi, Reiko. 1990. "Rhythmicity, Sequence and Synchrony as Floor Management in English and Japanese Face-to-Face Conversation.” Language Sciences 12: 155-195. 
Hayashi, Reiko. 1991. "Floor Structure of English and Japanese Conversation.” Journal of Pragmatics 16: 1-30.

Holmes, Janet. 1995. Women, Men and Politeness. New York: Routledge.

Jaworski, Adam, Nikolas Coupland, and Dariusz Galasiński. 2004. “Why now?” In Metalanguage:

Social and Ideological Perspectives, ed. by Adam Jaworski, Nikolas Coupland, and Dariusz

Galasiński, 3-8. New York: Mouton de Gruyter.

Jiang, Tao. 2008. 商务礼仪 [Commercial Etiquettes]. Beijing, China: Chinese Press.

Jin, Zhengkun. 2007. 官场礼仪 [Etiquettes in Public Relations]. Xi'an, China: Shaanxi Normal

University Press.

Jin, Zhengkun. 2008. 职场礼仪 [Workplace Etiquettes]. Beijing, China: China Renmin University Press.

Kádár, Daniel. 2012. "Historical Chinese Politeness and Rhetoric: A Case Study of Epistolary Refusals." Journal of Politeness Research 8 (1): 93-110.

Kádár, Dániel. 2013. Relational Rituals and Communication: Ritual Interaction in Groups. Basingstoke, UK: Palgrave Macmillan.

Kádár, Dániel, and Michael Haugh. 2013. Understanding Politeness. Cambridge: Cambridge University Press.

Kádár, Dániel, and Yuling Pan. 2011. "Politeness in China." In Politeness in East Asia, ed. by Dániel Kádár, and Sara Mills, 125-146. Cambridge: Cambridge University Press.

Kuang, Xiaorong. 2005. “口语交谈中的话语打断现象 [Interruption in Chinese colloquial conversation]”. Rhetoric Learning 4: 74-78.

Kuang, Xiaorong. 2006. “汉语口语交谈中的话语重叠现象 [The overlapping of discourse in Chinese colloquial conversation]”. Journal of College of Chinese Language and Culture of Jinan University 2: 57-65.

Kuhn, Deanna. 1991. The Skills of Argument. Cambridge: Cambridge University Press.

Labov, William. 1972. Sociolinguistic Patterns. Philadelphia, Pennsylvania: University of Pennsylvania Press.

Lakoff, Robin. 1973. “The Logic of Politeness, or Minding your p's and q's." Chicago Linguistics Society 9: 292-305.

Langlotz, Andreas, and Miriam A. Locher. 2012. "Ways of Communicating Emotional Stance in Online Disagreements.” Journal of Pragmatics 44: 1591-1606.

Leech, Geoffrey. 1983. Principles of Politeness. London, UK: Longman.

Lee-Wong, Song Mei. 1994. "Imperatives in Requests: Direct or Impolite-Observations from Chinese." Pragmatics 4 (4): 491-515.

Lee-Wong, Song Mei. 2000. Politeness and Face in Chinese Culture. Frankfurt: Peter Lang.

Levinson, Stephen C. 1983. Pragmatics. Cambridge: Cambridge University Press.

Li, Charles, and Sandra Thompson. 1981. Mandarin Chinese: A Functional Reference Grammar. Berkeley and Los Angeles: University of California Press.

Li, Han Z. 1999. "Grounding and Information Communication in Intercultural and Intracultural Dyadic Discourse.” Discourse Processes 28 (3): 195-215.

Li, Han Z. 2001. "Cooperative and Intrusive Interruptions in Inter- and Intracultural Dyadic Discourse." Journal of. Language and Social Psychology 20 (3): 259-284.

Li, Xiaoting. 2014. "Leaning and Recipient Intervening Questions in Mandarin Conversation." Journal of Pragmatics 67: 34-60.

Liao, Meizhen. 2009. "A Study of Interruption in Chinese Criminal Courtroom Discourse." Text \& Talk 29 (2): 175-199.

Lin, Yutang. 1939. My Country and My People. London: William Heinemann. 
Liu, Hong. 1992. “话轮、非话轮和半话轮的区分 [Turn, non-turn and semi-turn]”. Foreign Language Teaching and Research 3: 17-24.

Liu, Hong. 2004. 会话结构分析 [Conversation Structure Analysis]. Beijing: Peking University Press.

Liu, Senlin. 2007. “话语更迭的语用策略 [Turn-taking pragmatic strategies]”. Foreign Language Education 28 (4): 34-38.

Locher, Miriam A. 2004. Power and Politeness in Action: Disagreements in Oral Communication. New York: Mouton de Gruyter.

Locher, Miriam A. 2006. "Polite Behavior within Relational Work: The Discursive Approach to Politeness." Multilingua 25 (3): 249-267.

Locher, Miriam A., and Richard Watts. 2005. Politeness and Relational Work. Journal of Politeness Research 1 (1): 9-35.

Ma, Chunyan. 2014. “再论“话轮”的判断标准 [Discussing turn-taking again]”. Language Teaching and Linguistic Studies 1: 97-104.

Mills, Sara. 2003. Gender and Politeness. Cambridge: Cambridge University Press,.

Mills, Sara. 2009. “Impoliteness in a cultural context." Journal of Pragmatics 41 (5): 1047-1060.

Mills, Sara. 2011. "Discursive Approaches to Politeness and Impoliteness." In Discursive Approaches to Politeness, ed. by Linguistic Politeness Research Group, 19-56. Berlin and New York: Mouton de Guryter.

Mori, Junko. 1999. Negotiating Agreement and Disagreement in Japanese: Connective Expressions and Turn Construction. Philadelphia, Pennsylvania: John Benjamins.

Murata, Kumiko. 1994. "Intrusive or Co-operative? A Cross-Cultural Study of Interruption." Journal of Pragmatics 21: 385-400.

Murray, Stephen O. 1985. “Toward a Model of Members' Methods for Recognizing Interruptions." Language in Society 14 (1): 31-40.

Natale, Michael, Elliot Entin, and Joseph Jaffe. 1979. "Vocal Interruptions in Dyadic Communication as a Function of Speech and Social Anxiety." Journal of Personality and Social Psychology 37: 865-878.

Ng, Sik Hung, Mark Brooke, and Michael Dunne. 1995. "Interruption and Influence in Discussion Groups." Journal of Language and Social Psychology 14 (4): 369-381.

Nodoushan, Mohammad Ali Salmani. 2012. "Rethinking Face and Politeness." International Journal of Language Studies 6 (4): 119-140.

Pan, Yuling. 2000a. Politeness in Chinese Face-to-Face Interaction. New York: Ablex Publishing Corporation.

Pan, Yuling. 2000b. "Facework in Chinese Service Encounters." Journal of Asian Pacific Communication 10 (1): 25-61.

Pan, Yuling, and Dániel Kádár. 2011. Politeness in Historical and Contemporary Chinese. New York: Continuum International Publishing Group.

Rose, Kenneth, and Connie Ng. 2001. "Inductive and Deductive Teaching of Compliments and Compliment Responses." In Pragmatics in Language Teaching, ed. by Gabriele Kasper, and Rosse Kenneth, 145-170. Ernst Klett Sprachen.

Sacks, Harvey, Emanuel A. Schegloff, and Gail Jefferson. 1974. "A Simplest Systematics for the Organization of Turn-Taking for Conversation." Language 50 (4): 696-735.

Schegloff, Emanuel A. 2000. "Overlapping Talk and Organization of Turn-Taking for Conversation." Language in Society 29: 1-63. 
Schegloff, Emanuel A. 2001. "Accounts of Conduct in Interaction: Interruption, Overlap and Turn-Taking." In Handbook of Sociological Theory, ed. by Jonathan H. Turner, 287-321. New York: Kluwer Academic/ Plenum Publishers.

Schiffrin, Deborah. 1987. Discourse Markers. Cambridge: Cambridge University Press.

Schneider, Klaus P. 2012. "Appropriate Behavior across Varieties of English.” Journal of Pragmatics 44 (9): 1022-1037.

Spencer-Oatey, Helen. 2008. “Face, (Im)politeness and Rapport.” In Culturally Speaking: Culture, Communication and Politeness Theory, ed. by Helen Spencer-Oatey, 11-47. London: Continuum.

Spencer-Oatey, Helen, and Wenying Jiang. 2003. "Explaining Cross-Cultural Pragmatic Findings: Moving from Politeness Maxims to Sociolinguistic Interactional Principles (SIPs).” Journal of Pragmatics. 35 (10-11): 1633-1650.

Tannen, Deborah. 1984. Conversational Style. Norwood, NJ: Ablex.

Tao, Hongyin. 1996. Units in Mandarin Conversation: Prosody, Discourse, and Grammar. Amsterdam/Philadelphia: John Benjamins.

Ulijn, Jan M., and Xiangling Li. 1995. "Is Interrupting Impolite? Some Temporal Aspects of Turn-Taking in Chinese-Western and other Intercultural Business Encounters." Text 15 (4): 589-627.

Watts, Richard. 2003. Politeness. Cambridge: Cambridge University Press.

Watts, Richard. 2005. "Linguistic Politeness and Politic Verbal Behavior: Reconsidering Claims for Universality." In Politeness in Language: Studies in Its History, Theory and Practice, ed. by Richard Watts, Sachiko Ide, and Konrad Ehlich, 43-71. New York: Mouton de Gruyter.

Wu, Ruey-Jiuan Regina. 1997. "Transforming Participation Frameworks in Multi-Party Mandarin Conversation: The use of Discourse Particles and Body Behavior." Issues in Applied Linguistics 8 (2): 97-117.

Wu, Ruey-Jiuan Regina. 2011. "A Conversation Analysis of Self-Praising in Everyday Mandarin Interaction.” Journal of Pragmatics 43: 3152-3176.

Wu, Ruey-Jiuan Regina. 2012. "Self-praising through Reporting: Strategic Use of Two Reporting Practices in Mandarin Conversation." Discourse Processes 49 (8): 622-659.

Wu, Ruey-Jiuan Regina. 2014. "Managing Turn Entry: The Design of EI -prefaced Turns in Mandarin Chinese." Journal of Pragmatics 66: 139-161.

Yang, Mayfair Mei-hui. 1994. Gifts, Favors, and Banquets: The Art of Social Relationships in China. New York: Cornell University Press.

Yang, Ping. 2011. "Nonverbal Aspects of Turn Taking in Mandarin Chinese Interaction." Chinese Language and Discourse 2 (1): 99-130.

Zhu, Weihua. 2014a. "Managing Relationships in Everyday Practice: The Case of Strong Disagreement in Mandarin.” Journal of Pragmatics 64: 85-101.

Zhu, Weihua. 2014b. "Rapport Management in Strong Disagreement: An Investigation of a Community of Chinese Speakers of English." Text \& Talk 34 (5): 641-664.

Zhu, Weihua, and Diana Boxer. 2013. "Strong Disagreement in Mandarin and ELFP: Aggressive or Politic?” Journal of Language Aggression and Conflict 1 (2): 194-224. 


\section{Appendix A}

Transcription conventions (adapted from Schiffrin 1987)

\begin{tabular}{ll}
\hline Speaker turn start & $:$ \\
Overlapping utterances & {[]} \\
Contiguous utterances after an interruption & $=$ \\
Omission & $\cdots$ \\
A short untimed pause & - \\
Long untimed intervals & (pause) \\
Laughter & @ \\
Emphasis & italics \\
Characteristics of the talk & (coughs) \\
Items in doubt & (indistinct) \\
\hline
\end{tabular}

\section{Appendix B}

Glossing abbreviations (adapted from Li and Thompson 1981) ${ }^{4}$

$\begin{array}{ll}\text { ASSOC } & \text { associative de } \\ \text { BA } & \text { bǎ (a marker for object promotion) } \\ \text { BEI } & \text { bèi (a coverb of the passive construction) } \\ \text { CL } & \text { classifier } \\ \text { CRS } & \text { currently relevant state le } \\ \text { CSC } & \text { complex stative construction de } \\ \text { GEN } & \text { genitive de } \\ \text { INT } & \text { interjection } \\ \text { NOM } & \text { nominalizer de } \\ \text { PFV } & \text { perfective aspect } \\ \text { PRT } & \text { particle } \\ \text { QM } & \text { question ma } \\ \text { QNA } & \text { question na } \\ \text { QNE } & \text { question ne } \\ \text { RF } & \text { reduce forcefulness } \\ \text { SA } & \text { solicit agreement ba } \\ \text { 1PL } & \text { first person plural pronoun } \\ \text { 1SG } & \text { first person singular pronoun } \\ 2 \mathrm{PL} & \text { second person plural pronoun } \\ 2 \mathrm{SG} & \text { second person singular pronoun } \\ 3 \mathrm{PL} & \text { third person plural pronoun } \\ 3 \mathrm{SG} & \text { third person singular pronoun } \\ & \end{array}$

4. This came from Tao (1996). 


\section{Author's address}

Weihua Zhu

University of Wisconsin-Madison

Department of Asian Languages and Cultures

1212 Van Hise Hall, 1220 Linden Drive

Madison, WI 53706

United States

wzhu34@wisc.edu 